\title{
Peculiarity of sapphire application in medicine
}

\author{
L.A.Lytvynov \\ Institute for Single Crystals, STC "Institute for Single Crystals", National \\ Academy of Sciences of Ukraine, \\ 60 Lenin Ave., 61001 Kharkiv, Ukraine
}

Received April 2, 2014

\begin{abstract}
Considered are the properties of sapphire which make it expedient for application in relatively new branches of medicine such as microsurgery, implantology, medical instrument making. Peculiarities of the use of sapphire and its advantages over the analogues are shown.
\end{abstract}

Рассмотрены свойства сапфира, которые делают его перспективным для применения в относительно новых областях медицины, таких как микрохирургия, имплантология, изготовление медицинского инструмента и приборов. Показаны характерные особенности использования сапфира, его преимущества и недостатки в сравнении с металлическими и керамическими аналогами.

Особливості застосування сапфіра в медицині. Л.А.Литвинов.

Розглянуто властивості сапфіра, які роблять його перспективним для застосування у відносно нових областях медицини, таких як мікрохірургія, імплантологія, виготовлення медичного інструменту і приладів. Показано характерні особливості використання сапфіра і його переваги та недоліки порівняно з металічними та керамічними аналогами.

\section{Introduction}

Medical-biological investigations carried out as long ago as 1977-1983 have shown that sapphire is not toxic for humans and does not cause changes in the functions of the central nervous system, liver, kidneys, protein and fat metabolism, and general reactivity. It does not possess carcinogenic, mutagenic, embryotrophic, or other types of remote effects. Collagen fibrillar capsule growing on the implant passes into bone and muscular tissue, which preserves the normal structure. In contrast to metals, electrically neutral sapphire is not carried by electrochemical reactions into lymph nodes and other parts of the body, does not cause immunodepression and other changes in the immune system, and does not lead to demineralization of adjacent bone tissue.

Inertness, including electrolytic passiveness, biocompatibility, corrosion resistance, and hardness distinct to sapphire, define its main fields of application in medicine: implants, medical instrument and devices making.

\section{Material and method}

Crystals meant for application in medicine were grown from super-pure $(99.995 \%)$ aluminum oxide by the method of EFG which makes it possible to produce profiled crystals with a shape close to that of the final products. The blanks obtained of such crystals were annealed at $1950^{\circ} \mathrm{C}$ to remove local stresses.

A porous, thin $(50-300 \mu \mathrm{m})$ surface-adjacent layer is formed during the growth of profiled single crystals. Capillary holes in the shapers are located in such a manner that the streams of gas-saturated melt flowing out of them collide with the wave reflected by the meniscus, thus shedding vor- 
tices only in the vicinity of the preset surface. The surface of implants contacting with bone tissue must be porous, so the pores are then opened up by mechanical treatment. In other cases the porous layer is completely removed.

The effort of tissue piercing with sapphire micro-scalpels was determined by piercing a membrane which simulated the properties of cornea.

\section{Results and discussion}

Sapphire implants (SI). The chemical composition of the bones has been immensely studied. However, implants interact with bone tissue not only chemically. Analysis of the first series of implantations testified that, despite the above-mentioned unique inertness of sapphire implants, they showed osteogenic activity in vivo. Investigation of this phenomenon led to conclude the necessity of a crystallographic approach to the problem of the boundary formation between sapphire and bone tissue [1].

Crystallographic aspects. Beyond other conditions, the rate of implant adaptation in the patient depends on the crystallographic conformity between the structures of the implant and the mineral component of the bone tissue (crystalline fibers contained in microfibrils). The mineral component is essential (for example, the content of the mineral component of lower jaw bone tissue is 0.91 to $1.46 \mathrm{~g} / \mathrm{cm}^{3}$ at a bone density of 1.72 to $1.77 \mathrm{~g} / \mathrm{cm}^{3}$ ), and so it is necessary to take into account the crystallographic interaction between the crystals of the bone tissue and the lattice of the implant. Such considerations are similar to heteroepitaxy and intergrowth of crystals.

Biochemical and biomechanical testing of implants made from crystals with different syngony and lattice parameters showed the advantages of sapphire. The values of linear and angular discrepancies between the crystal lattices of sapphire and hydroxylapatite were estimated. It was assumed that the atoms belonged to the same chain if the distances between their centers and the straight line did not exceed the ionic radius ( $1 \AA$ for $\mathrm{Ca}$ ions and $0.6 \AA$ for $\mathrm{Al}$ ions). The periodicity and the angles between the chain pairs were calculated, and the crystallographic indexes of the mutually conjugate chains and planes were determined. The total value of the linear and angular discrepancy between the chain pairs in $\mathrm{Ca}_{5}\left(\mathrm{PO}_{4}\right)_{3} \mathrm{OH}$ (the substance $A$ ) and sapphire (the substance $B$ ) was determined from the formula:

$$
\Delta=2 \frac{a_{A 1}-a_{B 1}}{a_{A 1}+a_{B 1}}+2 \frac{a_{A 2}-a_{B 2}}{a_{A 2}+a_{B 2}}+2 \frac{I_{A}-I_{B}}{I_{A}+I_{B}}
$$

In this expression, $a_{A 1}$ and $a_{A 2}$ denote the periodicity of the location of metal atoms along the first and the second chain; $I_{A}$ is the angle these chains make in the substance $A ; a_{B 1}, a_{B 2}, I_{B}$ are the parameters of the corresponding chain pair in the substance $B$.

According to the criteria of mutual orientation used while estimating the oriented growth of one substance on another substance [2], such a growth may take place only when the considered crystalline structures contain at least one pair of atomic chains with small linear $(<15 \%)$ and angular $\left(10-15^{\circ}\right)$ discrepancies. For sapphire this condition is satisfied [3]. The main distinctive feature of single crystal implants is their ability to form strong junctions with the mineral component of microfibrils at the crystallographic compliance with their structures.

The service life of implants depends on the structure of the "implant/bone tissue" interface, specifically on the system - fibrobone or bone in which the implants are integrated. Osseointegration of the SI is provided by an optimum tension value, which should be defined by taking into account the statistical average difference in strength and elastic modules. For dense bone (e.g. lower jaw), the stretch is $0.15 \mathrm{~mm}$. For the bone of upper jaw, which is less dense, the value of stretch increases up to $0.2 \mathrm{~mm}$. Less close fit leads to fibroosseous integration. To stimulate osteogenesis, it is expedient to not only provide a close fit of the implant in the bone bed and to create the retention points, but also to activate the surface. The presence of aggregates of point defects, the exit points of dislocations and micro-cracks on the SI surface, sharply diminishes the energy barrier of crystal nucleus formation and speeds up the process of joining. It is desirable that the implant surface adjacent to the bone tissue have pores measuring $100-300 \mu \mathrm{m}$ across. This will promote the intergrowth of bone tissue and increase the implant's adaptive potential.

Functional merits of the SI are clearly seen in the comparison of their basic, functional properties with those of the widely used titanium analogs. Mucous membrane 


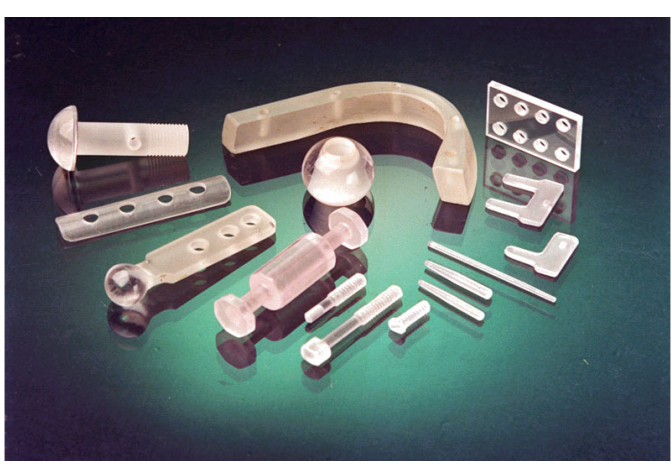

Fig. 1. Sapphire implants.

tightly encloses the SI neck, thus forming a cuff and preventing the penetration of bacterial infection into the gingival pocket over the interface between implant and bone tissue. The frequency of the adhesion events of gingival epithelium cells to the sapphire surface is 3 times higher than with titanium, even in the case when the sapphire has a coating applied by the plasma method. The loss of cortical layer (the bone tissue component which is most important for implant fixation) at the neck of the SI is considerably lower. This fundamentally influences the service life of the implants.

It is known that immunologic disturbances are defined by the implant material. The resistance of sapphire to any acid and alkali is immensely higher than that of metals and even of polycrystalline aluminum oxide. This likely explains the fact that sapphire does not change the immunological status of patients. At the same time, $73 \%$ of the cases involving metallic implant insertion are followed by immunodepression, changes of immunoreactivity, and other immunologic disturbances (especially for male patients). All these manifestations raise the probability of postoperative complications.

Histological investigations carried out at different terms of SI adaptation in patients lead to the conclusion that the service life of a correctly inserted implant is unlimited.

It is well-known that the nickel and chromium contained in some implants are carcinogenic, possess cytotoxic effects, and may affect allergies. Approximately $15 \%$ of people are especially sensitive to nickel, and $8 \%$ to chromium. Survival tests for L-132 cells (RPE, relative plating efficiency) placed in media of different implant materials for a long period of time show that aluminum oxide, platinum, and $\mathrm{TiAl}_{6} \mathrm{~V}_{4}$ alloy possess a level of survival close to $100 \%$. For Ni-Cr-Co alloy this characteristic is on the order of $23 \%$, while for $\mathrm{Ni}-\mathrm{Cr}-\mathrm{Mo}$ alloy it is even lower. The SI are

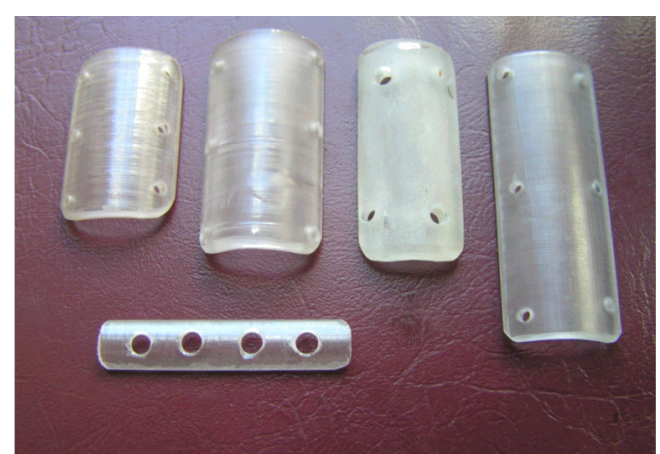

Fig. 2. Sapphire shells for spinoplasty.

especially suitable for those patients who suffer from intolerance to metals, or already have metallic implants inserted.

A number of implants and SI sets have been developed for orthopedics, traumatology, rhinoseptoplasty, spinoplasty, etc. (Fig. 1). The first sapphire vertebra implants of original design were successfully inserted in clinical trials by Academician A.A.Korzh in 1980 (Kharkiv). Thoracic and lumbar spinoplasty operations, which have no analogs in the rest of the world, are performed at the Kharkiv Regional Hospital (Ukraine). Specially developed for such operations are punched sapphire shells (Fig. 2), which allow control of the treatment process by means of nuclear magnetic resonance.

The use of dental SI allows stimulative regeneration of the tissues adjacent to the SI. This can be achieved by exploiting the high optical transparency of sapphire, which enables activation of the immune system and biological processes through transmission of $\mathrm{He}-\mathrm{Ne}$ laser radiation to the local, cellular level. The radiation finds its way into the polished head and endosal part of the implant via a flexible light guide and connector, then scatters at the boundary between the implant and the bone tissue. In this case, the implant functions as the final light guide. Several sessions of laser therapy arrest inflammation and reduce hyperemia, while subsequent sessions stimulate osteogenesis. This results in the formation of dense connective tissue around the endosal part of the implant with a tissue structure similar to that of normal, sound tissue. Only sapphire provides the possibility to utilize laser therapy for speeding up the adaptation of the implant.

At least 15 standard types of SI have been developed for maxillofacial surgery, such as lower jaw joints for children and adults, fixatives, jaw bone elongators, screws, etc. The implants are used at ankylosis, secondary deforming osteoarthritis, 


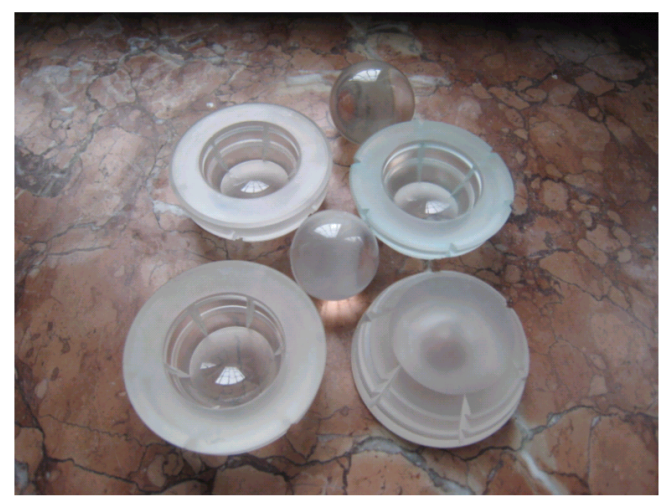

Fig. 3. Sapphire friction pairs for hip joint.

distal defects, and fractures of the condyle appendix of the lower jaw [4].

The use of sapphire in friction pairs is of particular interest. As a rule, orthopedic implants are of large size and, therefore, an essential amount of metal is introduced into the patient during traditional implantation. For instance, a hip joint endoprosthesis contains $300-350 \mathrm{~g}$ of titanium and alloyed steel (the latter being even less physiological). The metal corrosion products penetrate into the bone and may lead to traumatic osteomyelitis. The service life of the widely used metal-plastic hinges on hip joint prosthetics is insufficient (5-7 years) due to the high friction coefficient of the metal-polyethylene pair, which increases over time with use. The service life of joint prostheses depends on the quality of spherical surface polishing. Metallic and ceramic surfaces cannot maintain a high finish class because of the presence of disoriented grains and intergranular boundaries with different physical and mechanical characteristics than those of the grains. Different rates of wear of this microstructure raise the friction coefficient of the pair and lead to elevated wear of the mating component. The rough surface which is good for conventional intraosteal implants is undesirable for friction pairs. The probability of adherence of organic molecules to such a surface increases, thus deteriorating the performance of the friction pairs. Sapphire not containing block (grain) boundaries allows surfaces with a high polish quality to be obtained (possessing a slight roughness and containing practically no scratches and pits). Moreover, sapphire is one of the most wear-resistant materials. The friction coefficient of polished sapphire pairs (Fig. 3) actually decreases over the life of their operation; the wear index approaches the corresponding value of natural joints (Fig. 4).

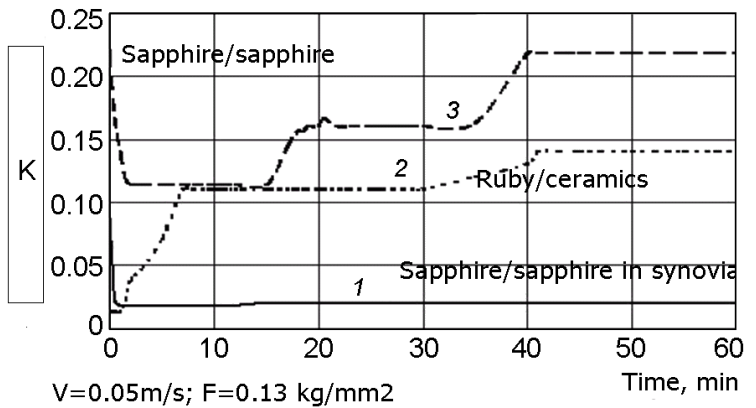

Fig. 4. Coefficients of friction.

The wear of the polyethylene component of polyethylene - alumina ceramic pairs (even if the latter is of low quality) is less then with polyethylene - zirconium dioxide pairs [5]. It is natural that for polyethylene coupled with sapphire this characteristic is much better compared to the two ceramics. Joint endoprostheses can be either entirely sapphire (e.g. those for lower jaw and shoulder joints) or combined metal sapphire structures (in particular, for hip joints). Comparative properties of friction pairs present in Table 1.

Sapphire surpasses metals in measures of hardness, wear resistance, and compression strength; however, its bending strength is lower. Therefore, for joint endoprostheses with sapphire heads the geometric parameters of the head and pedicle junction vary.

Nowadays more complicated sapphire implants are being developed. In particular, there are structures which consist of several mobile and one-piece elements (e.g. cardiac valves), intraocular lenses made of special sapphire which absorbs UV light, etc.

Clinical results. A check of maxillofacial SI carried out two years after implantation (Dr.Ryabokon, Prof.Kutsevlyak) showed that positive results (i.e. compete rehabilitation of the kinematics and chewing function, the absence of complaints, asymmetry, and disturbance of occlusion) were observed in $94.7 \%$ of all cases, while in the other $5.3 \%$ the results were satisfactory. For metallo-osteosynthesis the share of positive results was equal to only $69.5 \%$, the satisfactory and unsatisfactory results corresponded to $22.5 \%$ and $8 \%$ of the cases, respectively. Ultrasonic osteometry testified to a higher intensity of bone tissue growth on the implant for sapphire osteosynthesis [14].

Sapphire tools. To a considerable extent, achievements in microsurgery are defined by the sharpness of the cutting tools used. 
Table 1. Functional properties of friction pairs for endoprostheses of joints

\begin{tabular}{|c|c|c|c|c|}
\hline $\begin{array}{l}\text { Designa- } \\
\text { tion }\end{array}$ & Friction pair & Biological complications & Mechanical complications & $\begin{array}{l}\text { Peculiarity of } \\
\text { application }\end{array}$ \\
\hline $\mathrm{Me} / \mathrm{Me}$ & (Co-Cr)-steel/metal & $\begin{array}{c}\text { Inflammatory pseudotumors, } \\
\text { tissue necrosis, osteolysis } \\
\text { [1], lymphocytic cell } \\
\text { reactions corresponding to } \\
\text { various pathological } \\
\text { processes [2], cytotoxic } \\
\text { action of metal ions [7] }\end{array}$ & Wear of metals & $\begin{array}{l}\text { For elderly } \\
\text { and inactive } \\
\text { patients }\end{array}$ \\
\hline $\mathrm{Me} / \mathrm{P}$ & Metal/polyethylene & $\begin{array}{l}\text { Allergy to metals, osteolysis } \\
\text { (of some patients), } \\
\text { macrophages, granulomatous } \\
\text { changes in tissues }\end{array}$ & Wear of polyethylene & $\begin{array}{l}\text { For elderly } \\
\text { and inactive } \\
\text { patients }\end{array}$ \\
\hline $\mathrm{Ni} / \mathrm{P}$ & Ni-alloy/polyethylene & $\begin{array}{l}\text { Macrophages, granulomatous } \\
\text { changes in tissues, changes } \\
\text { in immune status }\end{array}$ & Wear of polyethylene & $\begin{array}{l}\text { Use of Ni- } \\
\text { alloys is } \\
\text { limited by } \\
\text { European } \\
\text { Directive [8] }\end{array}$ \\
\hline $\mathrm{Ti} / \mathrm{P}$ & Ti-alloy/polyethylene & $\begin{array}{l}\text { Macrophages, granulomatous } \\
\text { changes in tissues, eczemas } \\
\text { and inflammations [4], } \\
\text { electrochemical metal transfer }\end{array}$ & Wear of polyethylene & $\begin{array}{l}\text { For elderly } \\
\text { and inactive } \\
\text { patients }\end{array}$ \\
\hline $\mathrm{S} / \mathrm{S}$ & Sapphire/sapphire & Absent $[1,3,5,10-13]$ & $\begin{array}{c}\text { Fractures are possible at } \\
\text { incomplete relaxation of } \\
\text { stresses at incomplete } \\
\text { relaxation of stresses }\end{array}$ & $\begin{array}{c}\text { For all } \\
\text { patients, } \\
\text { especially for } \\
\text { young and } \\
\text { active } \\
\text { patients }\end{array}$ \\
\hline $\mathrm{C} / \mathrm{Z}$ & $\begin{array}{l}\text { Sapphire/Zirconium } \\
\text { oxide }\end{array}$ & $\begin{array}{c}\text { Absent, friction coefficient } \\
\text { is lower than that of } S / S \\
{[9,13]}\end{array}$ & $\begin{array}{c}\text { Fractures are possible at } \\
\text { incomplete relaxation of } \\
\text { stresses }\end{array}$ & $\begin{array}{c}\text { For all } \\
\text { patients, } \\
\text { especially for } \\
\text { young and } \\
\text { active patients }\end{array}$ \\
\hline $\mathrm{Ce} / \mathrm{Ce}$ & $\begin{array}{l}\text { Aluminum oxide } \\
\text { ceramics, BIOLOX } \\
\text { forte }\end{array}$ & Absent [6] & $\begin{array}{c}\text { Destructions are possible } \\
\text { at violations of synthesis } \\
\text { conditions }\end{array}$ & $\begin{array}{c}\text { For all } \\
\text { patients, } \\
\text { especially for } \\
\text { young and } \\
\text { active patients }\end{array}$ \\
\hline
\end{tabular}

Maximum achievable blade sharpness depends on the hardness of the material. Diamond is very expensive, and the size of diamond articles is limited by nature itself. Sapphire, second after diamond in hardness, allows fabrication of tools of any size. The production of sapphire, including profiled growth, is well-developed, so sapphire cutting tools of practically any size and shape can be manufactured. Due to their high hardness and chemical inertness in any media (including those of the patient), sapphire microscalpels are used in all the branches of microsurgery; large-size scalpels are employed in general surgery.

Since sapphire scalpels possess a high sharpness, they are less traumatic than metallic scalpels, require a lower pressure for puncturing tissue (Table 2), and require less effort for cutting. Owing to this fact, the
Table 2. Dependence of the effort for puncturing the tissue on angle sapphire microscalpel

\begin{tabular}{|c|c|}
\hline Effort, $\mathrm{g}$ & Angle, degree \\
\hline 2 & 20 \\
5 & 30 \\
12 & 45 \\
20 & 60 \\
\hline
\end{tabular}

loss of endothelial cells is reduced. Moreover, the blade sharpness influences the probability of forming cheloid and hypertrophic post-operative scars, as well as the probability of remission at their excision. The achieved sharpness depends on the crystallographic peculiarities of the sharpened planes and runs the range of 400 to $500 \AA$, which corresponds with the cross-section of 
tissue fibers. The key application fields for microscalpels are ophthalmology, neurosurgery, cosmetology, otolaryngological surgery, and dentistry.

For some operations, especially for those conducted under microscope, the microscalpels made of blue sapphire are more efficient; such tools are contrast better against the background of tissues.

There are also designed 20-degree microscalpels which have no analog among nonmetallic scalpels. The record blade thickness achieved for nonmetallic scalpels is $0.15 \mathrm{~mm}$; super-thin blades are made of strengthened sapphire. For abdominal operations knives are produced with a length of $10-35 \mathrm{~mm}$. Such instruments cannot be manufactured of diamond for economic reasons. The cost of sapphire scalpels is an order lower compared to analogous diamond scalpels.

The transparency of sapphire allow realization of a unique procedure consisting of the introduction of a single-mode laser beam through a flexible light guide, through the sapphire blade, and directly into the cutting zone. Besides the therapeutic effects and better visualization of the blade edge, such scalpels have another significant advantage. They make it possible to simultaneously illuminate and determine the exact location of capillary vessels, nerves, and other anatomical formations both in the cutting zone and during the advance of the blade, as well as more effectively control the cutting depth. The effect of inner illumination can be created. If a micro defect is formed on the cutting edge, it is instantly revealed to the surgeon due to the specificity of light reflection at this point.

Clinical results testify that, in comparison with traditional surgical instruments, sapphire tools shorten the duration of operations, speed up reparative processes, reduce the period of rehabilitation, and limit the probability of infection. This provides a better clinical outcome of recovery of lost functions of nerves, plexuses, etc.

Sapphire in medical equipment. Sapphire possesses higher chemical purity and inertness than most constructional materials. Blood components are not damaged while in contact with sapphire surfaces polished to a high finish class. Sapphire withstands considerable laser loads while maintaining good transmission in the IR-region of the spectrum. For instance, at the wavelength of Er:YAG-laser radiation $(2.94 \mu \mathrm{m})$ the ab-

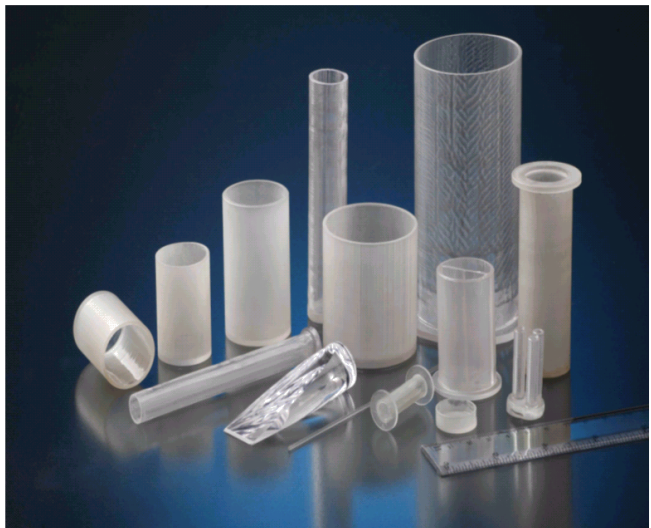

Fig. 5. Sapphire chemical ware.

sorption of sapphire is far less than that of glass, and sapphire withstands loads higher than $1 \mathrm{~kJ} / \mathrm{cm}^{2}$ without damage. These properties define the use of sapphire in medical equipment, for example:

- pumps for the transfer of blood and other substances (tubes, plungers, valves, pump casings);

- endoscopes (tips of different shapes);

- laser surgical Nd:YAG- and Er:YAGbased apparatuses, laser IR-scalpels (conical sapphire contact tips for dissection, hemispherical tips for evaporation, and cylindrical tips for coagulation of tissues in contact with the light guide window);

- equipment for obtaining high-purity medical preparations: crucibles, cuvettes, tubes, reactors (Fig. 5).

Application fields for sapphire continue to become wider and wider. As an example, the "sapphire room" concept should be mentioned. A medical project has recently been proposed (but not implemented at present) devoted to making a special room clad with artificial or natural sapphire. Medical chambers based on the generation of electromagnetic fields of different configurations inside closed space are well-known. In the opinion of the authors of Russian Patent No.2030909, the crystalline field of sapphire can interact with the human biological field, thus stimulating the reserves of the patient for overcoming certain diseases or favoring relaxation.

\section{Conclusions}

In contrast to metals, electrically neutral sapphire is not carried by electrochemical reactions into lymph nodes and other parts of the body, does not cause immunodepression and other changes in the immune system, and does not lead to demineralization of adjacent bone tissue. But there are not 
ideal friction pairs which properties are on a par with those of natural structures. The advantages of non-metallic friction pairs are based on their biological inertness, electrochemical neutrality, low wear, long service life.

Sapphire micro-scalpels provide lower tissue piercing effort and lesser loss of endothelium cells than their metallic analogues. Owing to illumination of the cutting zone through transparent blade, surgeon can control the process of operation more effectively. Blue sapphire blades are more contrasting and effective for operations performed using a microscope. Sapphire details of medical apparatuses are inert, non-trombogenic, not damaged by components of blood. Sapphire chemical wares are more corrosion resist than quartz or platinum, especially at a high temperature and aggressive environment.

\section{References}

1. E.Dobrovinskaya, L.Lytvynov, V.Pischik, Sapphire. Material, Manufacturing, Application, Springer, New York (2009).

2 G.V.Chaplygin, Compregensive Abstracts of Int. Confer. Crystal Growth., AN SSSR, Moscow (1980), v.1, p.135.
3. L.A.Lytvynov, Izvestia AN SSSR.Fiz.Seria, 52, 1911 (1988).

4. V.I.Kutsevlyak, E.N.Ryabokon, L.A.Lytvynov, Bull. Probl. Modern Med., No.9, 28 (1994).

5. J.Fudjioka-Hirai et al., Biomed. Mater. Res., 21, 913 (1987).

6. Cera News, 2, p. 8 (2013),

7. Clinophatological Study of Metal-on-Metal Hips Revised for Suspected Adverse Reactions to Metal Debris, ed. by S.Gurlaj, Springer Verlag (2013).

8. European Parliament and Council Directive 94/27/EEC

9. Ph.Thomas et al., J.Bone Joint Surg.Am., 93 (2011).

10. A.Mamalis et al., J. Biolog. Phys. and Chem., 7, 3 (2007).

11. Tadeusz Niedzwiedzki et al., Orthopedic and Traumatology, No.4, 92 (2007).

12. J.Gawlic et al., Tribologia, 3, 59 (2005).

13. Human Joint Endoprostheses. Materials and Technology, in: ed. by N.Novikov, ISM NASU, Kiev (2011), p.528. [ in Russian]

14. E.N.Ryabokon, Abstr. of Thesis. Ukrainian Med. Stomat. Academia, Poltava (1995), p.20. 